\title{
Melatih Paduan Suara secara Kreatif
}

\author{
Carrey Fressly Nanuru \\ Institut Agama Kristen Negeri Ambon
}

\begin{abstract}
Training the choir is one of the ones conducted to help everyone who in terms of singing, to prepare itself to achieve objectives have been very low. Train a chorus that good is the one conducted with full of creativity, to produce maximum results to meet calls will be the task and responsibility of the chorus in his ministry.
\end{abstract}

Keywords: church music; creative choir; choir

\begin{abstract}
Abstrak: Melatih paduan suara merupakan salah satu proses yang dilakukan untuk membantu setiap orang yang kurang dalam hal bernyanyi, untuk mempersiapkan dirinya mencapai tujuan yang maksimal. Melatih paduan suara yang baik adalah proses yang dilakukan dengan penuh kreativitas, sehingga menghasilkan hasil yang maksimal untuk memenuhi keterpanggilan akan tugas dan tanggung jawab paduan suara dalam pelayanannya.
\end{abstract}

Kata Kunci: paduan suara; paduan suara kreatif; musik gereja

\section{Pendahuluan}

Musik merupakan salah satu bagian terpenting dalam kehidupan manusia. Dikarenakan banyak orang yang menggunakan musik sebagai media penyamangat dalam melakukan aktifitas baik secara individual maupun secara umum. Bukan hanya itu, melainkan banyak yang menggunakan musik sebagai, media pembelajaran, relaksasi, bahkan ritual. Baik secara adat tradisi maupun secara peribadahan di gereja. Secara umum, musik dapat dibagi menjadi dua yaitu musik instrumental dan musik vokal. Musik instrumental adalah bunyi yang dihasilkan melalui bantuan alat musik. Sedangkan musik vokal adalah bunyi yang dihasilkan melalui suara manusia. Seperti Accapela (nyanyian yang hanya berupa vokal tanpa iringan) akan tetapi vokal dan iringan bisa jalan secara bersamaan seperti penyanyi solo maupun paduan suara.

Paduan suara meruapakan salah satu unsur musik dalam peribadahan bergereja, terkhususnya dihari minggu. Dikarenakan paduan suara dapat memberikan pengaruh yang kuat bagi jemaat dalam kelangsungan ibadah itu sendiri. Hal ini datang dari respons jemaat terhadap pelayanan paduan suara dan semangat angota paduan suara untuk memenuhi pelayanannya sekaligus kelangsungan ibadah. Akan tetapi, ada hal yang terjadi dalam paduan suara ketika membawakan lagu pujiannya terkadang kurang maksimal, sehingga mempengaruhi implikasi terhadap lagu pujiannya. Hal ini terjadi karena pengaruh latihan yang kurang efektif berdasarkan pelatih yang kurang kreatif dalam melatih paduan suara. 
Berhubungan dengan judul diatas, maka yang menjadi pertanyaan adalah, apa itu melatih paduan suara secara kreatif? Mengapa hal itu penting? Dan bagaimana hal itu dilakukan?

\section{Pengertian Paduan Suara}

Pada umumnya paduan suara merupakan satu kelompok paduan yang sudah tidak asing lagi bagi jemaat ataupun masyarakat. Akan tetapi, sering kali orang mengartikan paduan suara hanya sekelompok orang yang suka bernyanyi kapan saja dimana dia suka untuk bernyanyi. Pendapat ini sebenarnya tidak juga dikatakan salah, tetapi lebih tepatnya jika mengetahui seperti apa paduan suara yang sebenarnya.

Paduan suara terdiri dari beberapa kategori berdasarkan suara masing-masing, yaitu; (1) paduan suara anak, terdiri dari suara tinggi (sopran), dan suara sedang (mezzo sopran). (2) paduan suara sejenis wanita, terdiri dari sura sopran, mezzo sopran, dan alto. (3) paduan suara sejenis pria, terdiri dari suara tenor, bariton, dan bass. (4) paduan suara campuran, terdiri dari suara sopran, alto, tenor, dan bass (Putri, 2013).

Paduan suara merupakan penggabungan dari berbagai penyanyi yang membawakan lagu baik secara unisono (nyanyian satu suara) maupun secara harmonisasi (terbagi dari beberapa suara). Baik itu harmoni dua suara (two voice harmony), harmoni tiga suara (three voice harmony), harmoni empat suara (four voice harmony), harmoni lima suara (five voice harmony), dan harmoni delapan suara (eight voice harmony) (Banoe, 2003). Paduan Suara adalah sebuah persekutuan yang disatukan menjadi satu kelompok penyanyi yang sudah dilatih untuk membawakan lagu secara bersama-sama dalam satu suara maupun lebih dan menggunakan musik pengiring maupun tidak. (Kartika, Mering, Sanulita, tanpa tahun hlm. 1).

Berdasarkan pendapat dari beberapa sumber diatas, maka dapat disimpulkan bahwa paduan suara merupakan satu kelompok pujian yang terdiri dari beberapa kategori paduan suara, baik itu paduan suara anak, sejenis wanita, sejenis pria, maupun campuran, dengan jenis suara masing-masing (sopran, mezzo sopran, alto, tenor, bariton dan bass) yang telah dilatih menjadi satu paduan yang utuh untuk membawakan lagu secara bersama-sama.

\section{Pelatih Paduan Suara}

Seorang pelatih yang melatih paduan suara, dia harus berperan sebagai pemimpin yang memiliki 3 sikap. Yaitu; (1) kewibawaan sebagai pemimpin yang disegani oleh anggota paduan suara. (2) ketegasan dalam mengatur dan mengarahkan tim untuk menuju suatu tujuan, sehingga menimbulkan rasa tanggung jawab terhadap setiap anggota dalam paduan suara. (3) otoritas atau wewenang untuk memutuskan dan melakukan sesuatu sesuai dengan kebutuhan tim dan kebijakan pemimpin dalam paduan suara (Kurniawan, Suharto, Raharjo, 2019).

Berbicara soal melatih paduan suara, berarti tidak bisa dipungkiri bahwa yang harus melakukannya adalah seorang pelatih. Untuk itu peran pelatih dalam melatih paduan suara, bukan hanya memikirkan untuk melatih teknik vokal saja, Akan tetapi, dia juga harus berperan untuk; (1) mengajarkan peserta paduan suara untuk perdoa sebelum memulai latihan. (2) mengajarkan sikap tubuh, pernafasan, artikulasi, intonasi, phrasering, vibrasi, resonansi, improvisasi dan ekxpresi. (3) mengajarkan cara membaca partitur dnngan sabar. (4) menjadi pengiring paduan suara (5) menjadi motivator dalam memberikan motivasi bagi anggota paduan suara. (6) dia harus memberikan contoh sebagai seorang pemimpin yang bijak. (7) menjadi sahabat yang baik bagi anggota paduan suara sebagai pendengar untuk masalah-masalah apa saja yang membuat setiap individu atau tim anggota paduan suara terganggu dalam proses 
latihan. (8) harus bisa memposisikan dirinya sebagai orang tua atau saudara dalam memperlakukan anggota paduan suara sebagai anak atau kakak dan adik sendiri, sehingga ada ketertarikan dari setiap anggota paduan suara yang merasa bahwa paduan suara adalah rumah bagi mereka sendiri (Kurniawan et al, 2019).

Sebagai seorang pelatih paduan suara, tidak hanya mengandalkan bakat atau talenta saja, karena menurut Piccanussa (M.K. Direksi 1), berpendapat bahwa menjadi seorang pemimpin, harus memiliki; (1) komitmen pribadi yang jelas dalam bersekutu, melayani, dan bersaksi melalui musik. (2) kepribadian yang menyenangkan. (3) pengetahuan tentang tradisi dan liturgi secara umum (baik gerejanya maupun gereja-gerja lain). (4) kemampuan musikal. Bukan hanya itu saja, akan tetapi seorang pelatih juga harus bisa menjadi conductor (dirigen) yang mampu dalam mengkomunikasikan berbagai ide musik (musical idea), isyarat (cue), nuansa (nuance), suasana jiwa/hati (mood), pengertian terhadap kelompok paduan yang dipandunya sehingga mereka dapat menyanyikan subuah lagu paduan suara dengan baik untuk mencapai tujuan yang diinginkan.

\section{Kreatif}

Berbicara tentang kreatif, berarti kita mempunyai wawasan berpikir yang luas dan berimajinasi tinggi. Menurut Nurlaela et al, (2019: iii) mereka berpendapat bahwa kreatif merupakan keterampilan yang berhubungan dengan kemampuan seseorang untuk mengolah pikiran dan menghasilkan ide-ide yang baru. Kemampuan berpikir tingkat tinggi merupakan bagian dari apa yang telah dipikirkan, yaitu kepandaian dalam pikiran seseorang untuk menghasilkan ide-ide yang baru. Hal ini menjadi sinkron dengan apa yang telah dikemukakan oleh Zimmerer dkk (2009, terjemahan Nurlaela et al, 2019: 58), bahwa kreativitas adalah keahlian dalam mengembangkan ide-ide yang baru untuk menciptakan cara yang baru dalam pandangan terhadap masalah dan peluang. Untuk itu, kemampuan berpikir kreatif sangat diperlukan agar kompetensi sumber daya manusia kita sebanding dengan negara-negara lain.

Kemampuan berpikir kreatif menurut Anwar et al, sebagaimana dikutip oleh Rudyanto (2014: 43), adalah cara baru dalam melihat dan mengerjakan sesuatu berdasarkan 4 aspek yaitu; (1) fluency (kemahiran) adalah kemampuan menghasilkan banyak pendapat/pandangan. (2) flexibility (fexibilitas) adalah kemampuan dalam membagikan arah pemikiran yang berbeda.

(3) originality (keaslian) yaitu variasi keahlian dalam memberikan pandangan terhadap pemikiran yang berbeda. (4) elaboration (keterincian) yaitu kemampuan merinci detail-detail tertentu.

Mardhiyana dan Sejati (2016: 679) mengemukakan bahwa Kreatifitas merupakan hasil dari proses berpikir kreatif. Kreativitas merupakan proses dalam menghasilkan karya baru yang tidak lazim dengan melibatkan aspek kognitif dan efektif, sehingga menyebabkan munculnya pemahaman baru, ide, solusi praktis, atau produk yang bermakna (Mardhiyana dan Sejati, 2016). Menurut adler, terjemahan dari Muhni (1997: 26) ia berpendapat bahwa manusia memiliki apa yang disebut Creative Self (diri Kreatif). Yang merupakan suatu sistem yang sangat pribadi, yang menerjemahkan organisme menjadi bermakna, dan selalu mencari pengalaman yang akan memimpin manusia memenuhi kehidupannya yang unik. Berdasarkan beberapa pendapat diatas, maka dapat disimpulkan bahwa kreatif merupakan kepandaian dalam pikran seseorang untuk berimajinasi, sehingga mampu menciptakan ide-ide yang baru dan menghasilkan kreativitas berupa karya-karya yang bersifat original (asli). 


\section{Melatih Paduan Suara Secara Kreatif}

\section{Apa itu melatih paduan suara secara kreatif?}

Melatih paduan suara secara kreatif bukanlah hal biasa yang dianggap sepeleh, dan bisa dilakukan oleh siapa saja yang tidak memiliki kemampuan musikal. Akan tetapi melatih paduan suara secara kreatif membutuhkan orang yang mempunyai kemampuan musikal yang tinggi baik secara otodidak maupun secara akademik. Orang yang memiliki kemampuan musikal secara otodiddak harus benar-benar mempunyai pengalaman yang luas dalam hal paduan suara dan keterlibatan sebagai seorang pelatih. Sedangkan orang yang memiliki kemampuan musikal secara akademik, harus memiliki kemampuan musikal dengan spesialisasi khusus sebagai pelatih paduan suara, dirigen, dan berkemampuan dalam menguasai vokal dan alat instrument tertentu (piano), sehingga mampu melatih paduan suara dengan baik untuk mencapai suatu tujuan.

Untuk itu, alangkah baiknya jika memilih orang untuk melatih paduan suara secara kreatif, maka pilihlah orang yang berkemampuan musikal secara akademik, berimajinasi tinggi, kepandaian dalam menciptakan ide-ide yang baru, mampu mengatasi masalah dengan bijak (jika dalam paduan suara ada masalah yang perlu diselesaikan), mempunyai kreasi-kreasi yang baru dalam melatih, mampu menjadi motivator kepada seluruh anggota paduan suara, dan berkepribadian sanguinis (menyenangkan dan memiliki nilai kreatif dalam diri). Menurut Siahaan (2005: 51) ia berpendapat bahwa melatih merupakan peranan seorang pelatih/dirigen sebagai pemersatu jiwa dari paduan suara, dan memiliki tugas dan tanggung jawab penuh atas kehidupan paduan suara. Jika dilihat dari sisi kerohanian seorang pelatih/dirigen, ia adalah seseorang yang penuh kasih, sangat dekat kepada Tuhan, keterpanggilan untuk melayani, dan menjadikan firman sebagai dasar dari setiap nyanyian yang diajarkan.

\section{Mengapa hal itu penting?}

Sangat penting, karena dengan melatih paduan suara secara kreatif, dapat menjadikan paduan suara itu penuh dengan kreatifitas, agar supaya paduan suara tetap kokoh (tidak mudah untuk non aktif dalam pelayanan), menjadikan anggota paduan suara tidak gampang bosan dan bersemangat dalam latihan, menjadikan anggota paduan suara menganggap bahwa paduan suara adalah rumah dimana mereka dibentuk untuk berkarya.

\section{Bagaimana hal itu dilakukan?}

Untuk melatih paduan suara secara kreatif juga, perlu dilakukan beberapa tindakan yaitu; (1) adaptasi. dalam tahap ini, perlu dilakukan pengamatan terhadap sikap dan karakter masingmasing anggota paduan suara untuk dikenali, mengetahui kebiasaan-kebiasaan apa saja yang ada dalam paduan suara untuk ditindak lanjuti. (2) modifikasi. dalam hal ini merupakan tindakan dalam mengubah sesuatu yang kurang/tidak benar, memperbaiki kebiasaan-kebiasaan membosankan menjadi menyenangkan. (3) eliminasi. Dalam tahap ini, perlu keberanian dan kebijaksanaan dalam mengambil keputusan. Karena harus mengurangi atau mengganti fungsi yang berlebihan didalam paduan suara. (4) adaptasi. Dalam tahap ini, tahap dimana ide-ide kreatif itu muncul dan diterapkan kepada paduan suara.

\section{KESIMPULAN}

Berdasarkan pembahasan dalam tulisan ini, maka dapat disimpulkan bahwa melatih paduan suara, bukanlah hanya sebatas melatih saja. Akan tetapi harus memiliki imajinasi yang tinggi dalam memikirkan sesuatu yang baru, harus berjiwa kepemimpinan, harus bijaksana, harus cerdas, harus rendah hati, harus berkepribadian yang menyenangkan, harus menjadi 
teladan bagi anggota paduan, harus penuh dengan kreasi, sehingga apa yang diterapkan dapat menghasilkan sebuah kreatifitas yang baru. Semoga para pelatih yang melatih paduan suara, terkhususnya untuk pelayanan di gereja, harus mempunyai kreatif dalam membangun dan memimpin paduan suara untuk mencapai suatu tujuan.

\section{REFERENSI}

Putri D. M. Rizki, (2013). Upaya meningkatkan kemampuan bernyanyi dalam kegiatan ekstrakurikuler paduan suara melalui pelatihan solfegio pada siswa kelas VII smp negeri 2 pangkah kabupaten tegal. Jurnal. 32.

Banoe, Pono. (2003). Kamus Musik. Yogyakarta: Kanisius. Hlm. 180.

Kurniawan C. Suharto, Raharjo E. (2019). Peran pelatih dalam membangun pelatihan paduan suara yang menyenangkan di paduan suara Voice Of Conservation (VOC) Universitas Negeri Semarang. Jurnal. 8(1), 13-21. 10.15294/jsm.v8i1.29207

Ibid., 13-21.

Kartika Wahyu, Mering Aloysius, Sanulita Henny. (tanpa tahun). Analisis peran pelatih paduan suara dalam meningkatkan keterampilan menyanyi peserta paduan suara di smk. 1-8

Picanussa B. E. (tanpa tahun). Direksi dalam musik. Seni Memimpin Kelompok Musikal (musik vokal, musik instrumental, gabungan musik vokal dan instrumental). hlm. 4-5

Nurlaela et al. (2019). Strategi Belajar Berpikir Kreatif. Jakarta utara: PT Media guru digital Indonesia. hlm. lii.

Ibid,. hlm. 58

Rudyanto H. E. (2014). Model discovery learning dengan pendekatan saintifik bermuatan karakter untuk meningkatkan kemampuan berpikir kreatif. Jurnal. 4(01), 41-48. 10.25273/pe.v4i01.305

Mardhiyana Dewi, Sejati E. O. Wahani (2016). Mengembangkan kemampuan berpikir kreatif dan rasa ingin tahu melalui model pembelajaran berbasis masalah. Jurnal. 672-688. https://journal.unnes.ac.id/sju/index.php/prisma/article/view/21686

Muhni D. A. Imam (1997). Manusia dan kepribadiannya (Tinjauan filsafat). Jurnal. 19-29. https://repository.ugm.ac.id/23822/

Siahaan Rohani (2005). Peranan paduan suara gereja dalam memperkukuh spiritualitas dan memberi konstribusi bagi ibadah jemaat. Jurnal. 3(1), 47-54. 10.25278/jj71.v3i1.143 